the angles. I have seen such men months afterwards with the calves of the legs and the ankles discolored as though the limb had been beaten or severely bruised. It may be stated in this connection that pellagra was not at that time recognized in this country.

\title{
THE MECHANISM OF THE MOUTH PARTS OF THE SQUASH BUG, ANASA TRISTIS DEGEER. ${ }^{1}$
}

\author{
By Daniel G. Tower, B.S.,
}

In preparing a previous paper dealing with the external anatomy of the squash bug (Tower, '13) it was found necessary to work out the structure of the mouth parts and internal anatomy of the head region. The mouth parts proved to be so interesting that a study more detailed than was possible in a general consideration of the anatomy has been made, the results being incorporated in the present paper. A brief description of the external region of the head and its parts has also been included so that one may more readily orient himself as to the relation of the parts to one another.

At this point I wish to thank Dr. H. T. Fernald for his assistance and the loan of books and pamphlets from his private library; and Dr. G. C. Crampton, who has directed my work and greatly assisted me in preparing this paper for publication.

As the sclerites of the head capsule are solidly fused together the general regions are all that can be described. Of these the occiput (occ), see Pl. 1 f. 1, lies behind the ocelli (oc) and forms the posterior portion of the head surrounding the occipital foramen. It is marked off by a shallow transverse groove, from the vertex. The vertex or cranium (v) comprises the dorsal region in front of the occiput and bears the ocelli. This area is not marked off from the frons (f), which lies above and between the bases of the antennæ. The anterior margin of the frons is united with the base of the clypeus (c).

Below and on either side of the compound eyes (e) lie the genæ (g), while the ventral posterior portion of the head capsule forms

1 Contribution from the Entomological Laboratory, Massachusetts Agricultural College. 
the gula (gu). The clypeus, as has been stated, is fused at its base with the frons, and at this point is narrow, but as it curves forward and downward it widens at its tip to form the base of attachment for the labrum (lbr) from which it is separated by a narrow membranous ring.

The labrum is an elongate triangular sclerite. Its anterior surface is convex, while its posterior surface is flat and contains a groove which lies above the groove on the basal half of the anterior surface of the labium (lab).

On either side of the clypeus is a narrow prolongation of the frons called the fulcrum (fr). The fulcra lie close to the lateral walls of the clypeus hiding them, but not united with them except at their bases, where they fuse with the head capsule.

The maxillary laminæ (lm) lie below the base of the antennæ (ant). Their bases are fused with the genæ and their ventral margins are united with the bucculæ (bu), which are chitinous plates projecting from the anterior ventral side of the head on either side of the base of the labium.

The labium articulates with the anterior ventral region of the head between the bucculæ. The labium contains, as stated above, a dorsal groove in which lie the setæ (s). The edges of the groove beyond, or distal to the overlying labrum, overlap, forming a closed tube, thus giving the enclosed setæ more support. At its basal end the groove becomes very shallow; the labium becomes filled with muscles, tracheæ and nerves, and the setæ in this portion of the labium gradually come to lie within the labrum, whose edges meet beneath and confine the setæ.

The setæ now pass back through the articulating membranes, which lies between the labrum and clypeus and between the lateral walls of the clypeus. The walls of the clypeus at its tip turn under, and their edges interlock, forming a narrow pair of supporting lobes above which the setæ pass. Upon emerging from these lobes the maxillary setæ $(\mathrm{m})$ spread apart to receive the tip of the pharynx and the canal from the salivary pump, both of which enter the setæ at this point.

The setæ represent the mandibles (md) and the maxillæ (m). The maxillæ are fluted and interlocked so as to form two tubes, namely the upper or suction canal (fc), and the lower or salivary canal (sc), see Pl. 1 f. 2. The mandibles are slightly shorter than 
the maxillæ and their tips are barbed. Their function is that of piercing the plant tissues and holding the setæ in place, while the tips of the maxillæ, which are acute and fluted, probe the plant tissues, take up the plant juices and eject the saliva.

At the point where the maxillary setæ diverge they are surrounded by a membranous sheath, which renders air tight their connections with the pharynx (ph) and with the salivary pump canal or efferent canal (ec). After separating, the maxillæ together with the mandibles pass back, one of each on either side of the pharynx. The above mentioned membranous sheath also extends back on either side of the pharynx and encloses the setæ, being fastened to their bases. Soon after the maxillary and mandibular setæ have separated, at their junction with the pharynx, the mandibles separate from the maxillæ and take up a position above them.

The bases of both the maxillæ and mandibles widen posteriorly, forming attachments for the muscles which operate them, especially the inner dorsal portion of the base of the maxillæ. This becomes thickened to form a prominent ridge to which the chitinous rod (h), see Pl. 1 f. 7 and Pl. 2 f. 9, which articulates with the genæ, is fastened by a short tendon. The rod runs downward between the setæ and the side of the pharynx, turning under the setæ, and here lies above the tentorial lobes, being embedded in a membrane which separates the muscles of the setæ from these lobes. Laterally the end of this crescent shaped rod is fastened to the under side of a small internal knob on the genæ (p) situated directly below the compound eye. Ventrally the rod is attached to the tentorial lobe, see Pl. $1 \mathrm{f}$. 7 .

The maxillary setæ are each controlled by two powerful muscles, both of which are attached directly to the bases of the maxillæ. These are the protractor muscle $\left(\mathrm{pm}_{1}\right)$, which extends anteriorly and is attached to the inside of the maxillary lamina and the side of the tentorial structure supporting the pharynx and salivary pump; and the retractor muscle which extends posteriorly and is attached to the occiput and also by a few fibres to the dorsal surface of the tentorial lobe.

Each mandibular seta is controlled by two series of muscles. The two retractor muscles (rm), see Pl. 1 f. 3, are attached directly 
to the base of the seta. A short upwardly directed one is attached behind the ocelli, a longer one extends posteriorly and is attached laterally to the walls of the occipital foramen. The protractor muscle (pm) is attached to the inside of the frons. This muscle instead of being directly attached to the base of the mandible, is attached to a small chitinous triangular plate (b) which articulates at one corner with the gena near the anterior margin of the latter just anterior to the base of the antenna. This triangular plate likewise articulates with the mandible by means of a small rod (a) which is attached at its posterior end to the base of the mandible, while its anterior end articulates with the ventral corner of the triangular plate. The muscle in contracting pulls the mandible forward by means of the small connecting rod. These protractor and retractor muscles control the piercing and probing of the maxillary setæ, and the piercing and holding of the plant tissues by the mandible.

The cavity of the pharynx (ph), which is larger in the middle than at either end, becomes continuous with that of the suction canal, in the setæ, at the point of divergence of the maxillary setæ. At this point the hypopharynx (hph), see Pl. 2 f. 12, or anterior portion of the ventral plate of the pharynx (which is a slender chitinous trough-shaped process) enters the suction canal and lies on the ventral floor of the latter, while the epipharynx, or anterior portion of the dorsal plate of the pharynx, lies above the setæ, fitting snugly over them, and extends anteriorly between the lobes of the clypeus. The membranous sheath surrounding the union of the pharynx and setæ make this union air tight.

The pharynx becomes constricted posteriorly as it passes between the circumœsophageal commissures, opening posteriorly into a membranous oesophagus. Posterior to this constriction the osophagus is enclosed by a sheath made up of longitudinal muscles. This sheath is connected with the wall of the occipital foramen dorsally by two transversely attached muscles, given off dorsolaterally from the muscular sheath, and ventually it is connected by two ventro-lateral muscles which diverge and are attached to the walls of the occipital foramen. This sheath extends from the posterior end of the pharynx back into the prothoracic region. The four muscles support the oesophagus in this region and probably by their movements of relaxing and contracting, together 
with the action of the longitudinal muscles of the sheath, play some part in passing the food down the œsophagus.

The pharynx is double $\mathrm{U}$-shape in cross section. The lateral margins of the dorsal plate ( $\mathrm{dp}$ ) are attached to the dorsal edges of the rigid chitinous ventral plate. To the dorsal surface of the dorsal plate are attached the powerful pharyngeal muscles ( $\mathrm{phm})$, see Pl. 1 f. 6, which retracting draw up the dorsal plate creating a vacuum thereby drawing the plant juices up through the suction tube of the setæ and into the pharynx.

The pharyngeal muscles are attached dorsally to the inside of the head capsule. There are three distinct series of pharyngeal muscles attached to the dorsal plate of the pharynx. The first or anterior series is short and composed of small muscles. They are attached to the dorsal plate just posterior to the epipharynx. The second is the longest series and is attached to the widened middle portion of the pharynx. The third or posterior series is attached to the more flattened upcurved posterior portion of the pharynx.

As the dorsal plate lies on the ventral plate, when the pharyngeal muscles are relaxed it seems reasonable to suppose that this pump acts in the following manner. The middle portion of the pharynx is filled when muscle series one contracts and is followed by the contraction of series two, the third series remaining relaxed while the middle portion of the pharynx is filling. When the middle portion is full the first series of muscles relaxes, allowing the dorsal plate to drop. The third series now contracts, opening the way into the osophagus as the second series relaxes forcing the contents of the pharynx down into the oesophagus. Series three now relaxes to complete the emptying of the pharynx. At the completion of this series of contractions and relaxations at the posterior end of the pharynx, no doubt a new series of similar contractions and relaxations begin again, or possibly they start just before the completion of the first series. As the above description describes a wave-like motion and as no distinct valves have been found as are seen in the salivary pump, the above described process is no doubt the correct one.

Anteriorly the hypopharynx is marked off from the remainder of the ventral plate of the pharynx by raised irregular thickenings situated at the base of the hypopharynx on its lateral walls. The epipharynx is similarly marked off from the remainder of the dorsal 
plate by corresponding thickenings on the dorsal plate. The epipharynx is also well marked off from the remainder of the dorsal plate because at this point the flexible dorsal plate ends and the portion beyond or epipharynx lies above the union of the setæ and bears ten papillæ. These irregular thickenings on the lateral walls of the dorsal and ventral plate interlock on either side of the canal of the pharynx. Upon a superficial examination these interlocking thickenings appear to be valvular, but closer observation shows them to be lateral to the canal and that the canal is closed by the dorsal plate of the pharynx being pressed against the ventral plate. Situated on the ventral surface of the epipharynx and above the diverging setæ there is, as stated above, a series of ten minute transparent papillæ arranged in pairs. It has been stated by some writers that these papillæ or glands secrete an oily substance which lubricates the setæ, which at this point must necessarily move forward and backward and in close contact with the epipharynx and hypopharynx. Others state that these are taste organs. The balance of opinion seems to be in favor of the latter view, although this point has not been sufficiently investigated.

Just posterior to the epipharynx on the dorsal plate of the pharynx there are four pairs of glands arranged in a line, each opening into the pharyngeal cavity. The nature of the secretions which these glands empty into the pharynx is not known, but probably they are digestive fluids. Above this series of glands is attached the first series of pharyngeal muscles.

Anteriorly and dorsally the pharynx is supported by two struts (n), seePl.2f. 11 and 13, situated lateral to the lateral dorsal portion of the pharynx. These struts diverge and extending upward fuse with the lateral walls of the clypeus. In addition to these the anterior portion of the ventral plate is supported by upward extending diverging lateral struts which fuse with the inner walls of the fulcra, see Pl. 2 f. 12. At the point where the setæ meet, the lateral walls of the clypeus pass down on either side of the epipharynx and setæ and meet beneath the setæ, thus forming the lobes of the clypeus (lc), see Pl. $2 \mathrm{f}$. 13. The pharynx is also supported by the tentorial structures, but this will be taken up later.

Below the anterior end of the pharynx lies the salivary pump (sp) supported by the tentorium. This very unique pump consists of a chitinous cylinder and piston. The cylinder is closed at 
its anterior end except for the two openings of the salivary ducts (sd) on its ventral side and the opening into the salivary pump canal or efferent canal (ec) in its anterior dorsal surface. Within the cylinder is a valvular flap (iv) which is attached posterior to the salivary ducts. This valve covers these ducts and allows the salivary juices to enter the cylinder from the salivary ducts, but does not permit it to flow back. The dorsal opening is closed by a long valvular flap (ov), attached to the dorsal wall of the efferent canal, which extends forward. This allows the salivary fluid to pass out of the pump and into the efferent canal, but not to return again into the cylinder. Normally the cylinder is nearly filled by the piston head or plunger ( $\mathrm{pl}$ ), see Pl. 1 f. 5, to which is attached anteriorly and laterally the elastic flexible membranous posterior wall of the cylinder. Posteriorly the piston head or plunger is attached to a piston rod to which are attached two large muscles (k) which diverge posteriorly and are attached to the posterior ventral region of the head and also by few muscle fibres to the ventral surface of the lobes of the tentorium. These muscles in contracting draw the plunger back creating a vacuum in the cylinder. This closes the dorsal outlet valve and opens the ventral or inlet valves causing the pump cylinder to fill with saliva from the salivary ducts. When the muscles relax, the elasticity of the posterior wall of the cylinder draws the plunger back into place, thereupon the ventral valves are closed and the dorsal one is opened and the saliva is forced out through the efferent canal and down the salivary canal in the setæ and into the plant tissues.

It seems not unreasonable to suppose that these salivary juices act on the plant cells chemically, possibly as a poison, and cause them to yield their juices more readily, although this point has not yet been investigated.

The efferent canal after leaving the pump cylinder extends forward in a straight line (being supported by a portion of the chitinous tentorium and gradually itself becoming chitinized) until it reaches the membranous sheath about the setæ which it penetrates, and then unites with the lower of salivary canal in the setæ.

The tip of the efferent canal which is trough-like and chitinized enters the salivary canal at the separation of the maxillary setæ and lies on the ventral surface of the salivary canal. The union is made air tight by the chitinous tentorial support of the efferent canal and the membranous sheath. 
As these unions of the pharynx and the efferent canal with the setæ must be more or less loose to allow for the forward and backward sliding movements of the setæ, as they are used in feeding, the membranous sheath must fit tightly in and about these parts to insure that there be no leakage at these two joints.

The tentorial structures are variously modified. The middle region of the ventral plate of the pharynx is supported by two chitinous plates which abut against and are attached to the posterior portion of the head in the gula region. These pass forward and upward as broad curved narrowing plates. They converge as they approach the pharynx and their inner edges turn up so that the ventral surfaces of the turned up portion lie along the sides of the ventral plate and are united by tendons to the ventral plate of the pharynx, see Pl. 1 f. 4 and 7 . These plates continue forward along the sides of the pharynx, their ventral surfaces extend further up the side of the pharynx. In cross section they appear somewhat crescent shaped as seen in Pl. 1 f. 6 (t). Lying on either side of the pharynx, they form a trough or bed in which the pharynx lies. Anteriorly the salivary pump lies below the pharynx and between these curved tentorial structures securely held in place by the connective tissue which surrounds it. Just anterior to the pump, portions of the two inner surfaces of the plates pass upward on either side of the efferent canal supporting it and continue with it to its connection with the setæ. A portion of each plate passes forward and slightly downward, fusing medianly, with that of the other side, below the portions which support the efferent canal to form the plate to which is attached the dorsal anterior surface of the labium.

Opposite the anterior end of the salivary pump, the outer margins of the plates roll upward and over the fused central plates, and form the two black heavily chitinized horns of the tentorium (ht), each of which contains a groove, which acts as a guide to the converging setæ, which meet over the tip of these horns and pass forward together above the lobes of the clypeus.

The horns of the tentorium separate posteriorly to allow the chitinized tip of the efferent canal and its supporting structures to pass upward between them and connect with the salivary canal in the maxillary setæ at the point where the setæ come together.

The lateral margins of the horns of the tentorium and the lateral margins of the plate to which the anterior dorsal surface of the 
labium is attached, are fused to the inside of the maxillary lamina and to the bucculæ along the line of union of the lamina with the bucculæ.

A very delicate chitinous rod (i) which broadens dorsally is situated internal to each compound eye. Each of these rods is attached to the dorsal surface of the same small knob-like projections of the genæ below the compound eyes, to which the chitinous rod that articulates with the base of the maxillary setæ is attached, see Pl. 1 f. 7 (p), and extending upward and slightly forward is attached just above the eye. These rods apparently act as protectors and supports of the eye structures and a few muscle fibres from the antennæ are attached to them dorsally.

There are two thick strong struts projecting inward from the head capsule, one on either side of the head, located slightly anterior to and inward from each ocellus. These form the base of attachment for most of the antennal muscles.

The labrum is a very flexible sclerite. It contains numerous muscles, tracheæ and nerves. The action of its muscular system has not been worked out.

The labium is controlled by two muscles, of these the protractor, or extensor, extends down the labium beneath the anterior surface and is attached basally to a small process of the tip of the tentorial plate to which the labium is attached. The retractor muscle extends down the labium posteriorly and basally is fastened to the ventral surface of the plate with which the labium articulates.

\section{BIBLIOGRAPHY.}

1883. Geise, Otto. Die Mundtheile der Rhynchoten, Archiv. f. Naturg., vol xlix, pp. 315-373, pl. X.

1885. Wedde, Hermann. Beiträge zur Kenntniss des Rhynchotenrüssels, Archiv. f. Naturg. (2) li. pp. 113-143, pls. VI and VII.

1892. Smith, John B. The Structure of the Hemipterous Mouth, Science, vol. xix, No. 478, pp. 189, figs. 1-5.

1896. Marlatt, C. L. The Hemipterous Mouth, Ent. Soc. of Wash. vol. iii, pp. 241-250, figs. 21-23.

1911. Muir, F. and Kershaw, J. C. On the Homologies and Mechanism of the Mouthparts of Hemiptera, Psyche, vol. xviii, No. 1, pp. 1, pls. 1-5.

1911. Bugnion, E. and Popoff, N. Les Pièces Buccales des Hémiptères (Première Partie), Arch. Zoöl. Expér. et Général, $5^{\ominus}$ Série, vol. vii, pp. 643-674.

1912. Muir, F. and Kershaw, J. C. The Development of the Mouthparts in the Homoptera with Observations on the Embryo of Siphanta, Psyche, vol. xix, No. 3, pp. 77, figs. 1-4.

1913. Tower, D. G. The External Anatomy of the Squash Bug, Anasa Tristis De G., Am. Ent. Soc. Amer., vol. VI, pp. 427-437, pls. LV-LVIII. 


\section{LETTERING OF FIGURES.}

$a=$ chitinous rod at base of mandible.

ant = antenna.

$\mathrm{b}=$ chitinous triangular plate articulating with genæ.

$\mathrm{b}$-ant $=$ base of antenna.

$\mathrm{bu}=$ bucculæ.

$\mathrm{c}=$ clypeus.

$\mathrm{dp}=$ dorsal plate.

$\mathrm{e}=$ eye.

$\mathrm{ec}=$ efferent canal.

$\mathrm{f}=$ frons.

$f c=$ food canal or suction canal.

$\mathrm{fr}=$ fulcrum.

$\mathrm{g}=$ genæ.

$\mathrm{gu}=$ gula .

$\mathbf{h}=$ chitinous rod connecting maxillary

setæ and genæ.

hc $=$ head capule.

hph = hypopharynx.

ht $=$ horns of the tentorium.

$\mathrm{i}=$ chitinous rod behind eye.

iv $=$ inlet valve.

$\mathrm{k}=$ retractor muscle of salivary pump.

l= struts to which some of the antenna muscles fasten.

$\mathbf{l a b}=$ labium . $\mathrm{lbr}=$ labrum.

$l c=$ lobes of the clypeus.

$\mathrm{m}=$ maxilla.

$\mathrm{md}=$ mandible.

$\mathrm{ml}=$ maxillary laminæ.

$\mathrm{n}=$ pharyngeal struts.

oc $=$ ocelli.

occ $=$ occiput.

ov $=$ outlet valve

$\mathrm{p}=$ internal knob below compound eye.

$\mathrm{ph}=$ pharynx.

phm $=$ pharyngeal muscles .

$\mathrm{pl}=$ plunger of pump.

$\mathrm{pm}=$ protractor muscle of mandible.

$\mathrm{pm}_{1}=$ protractor muscle of maxillæ.

pth $=$ prothorax.

$\mathrm{rm}=$ retractor muscle.

$\mathrm{s}=$ setæ.

sc $=$ salivary canal.

sd $=$ salivary duct.

$\mathrm{sg}=$ salivary glands.

$\mathrm{sp}=$ salivary pump.

$\mathrm{t}=$ tentorium.

$\mathrm{v}=$ vertex.

$\mathrm{vp}=$ ventral plate.

\section{EXPLANATION OF PLATES. \\ Plate I.}

Fig. 1. Side view of head.

Fig. 2. Cross section of setæ.

Fig. 3. Mandibular seta showing its connection with the gena.

Fig. 4. Cross section through the middle region of the pharynx.

Fig. 5. Longitudinal section of salivary pump.

Fig. 6. Cross section of the pharynx and salivary pump as seen in fig. 10.

Fig. 7. Cross section through the eyes. A diagrammatic drawing of fig. 9.

\section{Plate II.}

Figures 8-13 are microphotographs.

Fig. 8. Shows the salivary pump and efferent canal and the attachment of the labium. The horns of the tentorium are separated.

Fig. 9. Cross section of the head through the eyes.

Fig. 10. Cross section of the head through the bases of the antenne.

Fig. 11. Longitudinal section of the head showing the pharyngeal muscles, pharynx and salivary pump, their supports, and the position of the setæ.

Fig. 12. Shows the ventral plate of the pharynx, and the hypopharynx, which are supported by the struts running to the fulcra.

Fig. 13. Shows the position of the pharynx and setæ at their junction, behind the lobes of the clypeus.

\footnotetext{
${ }^{1}$ The microphotographs were taken by $T$. W. Nicolet, from slider prepared by the author.
} 


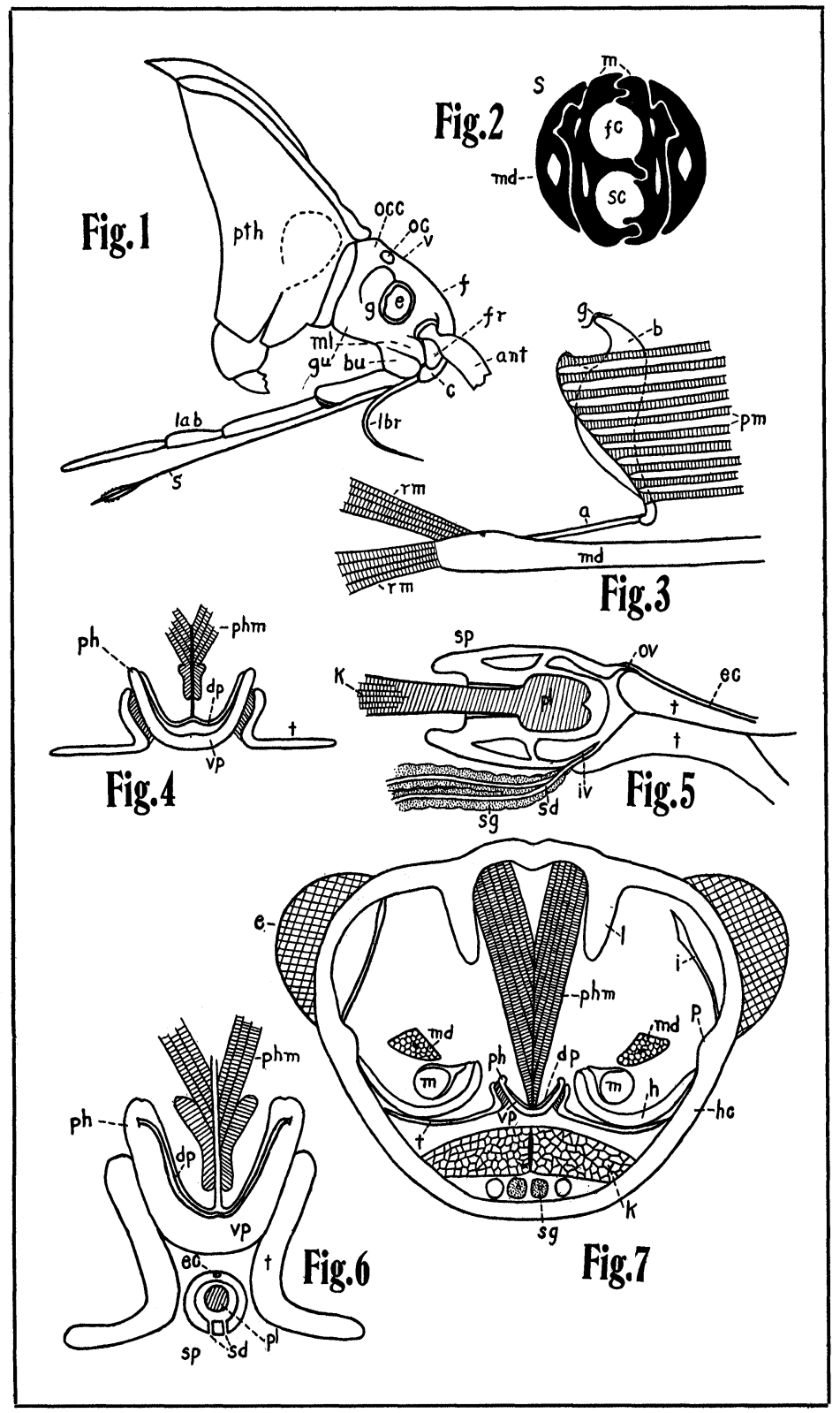

Tower-Mouth Parts of Squash Bug. 
Psyche, 1914.

Vol. XXI, Plate II.

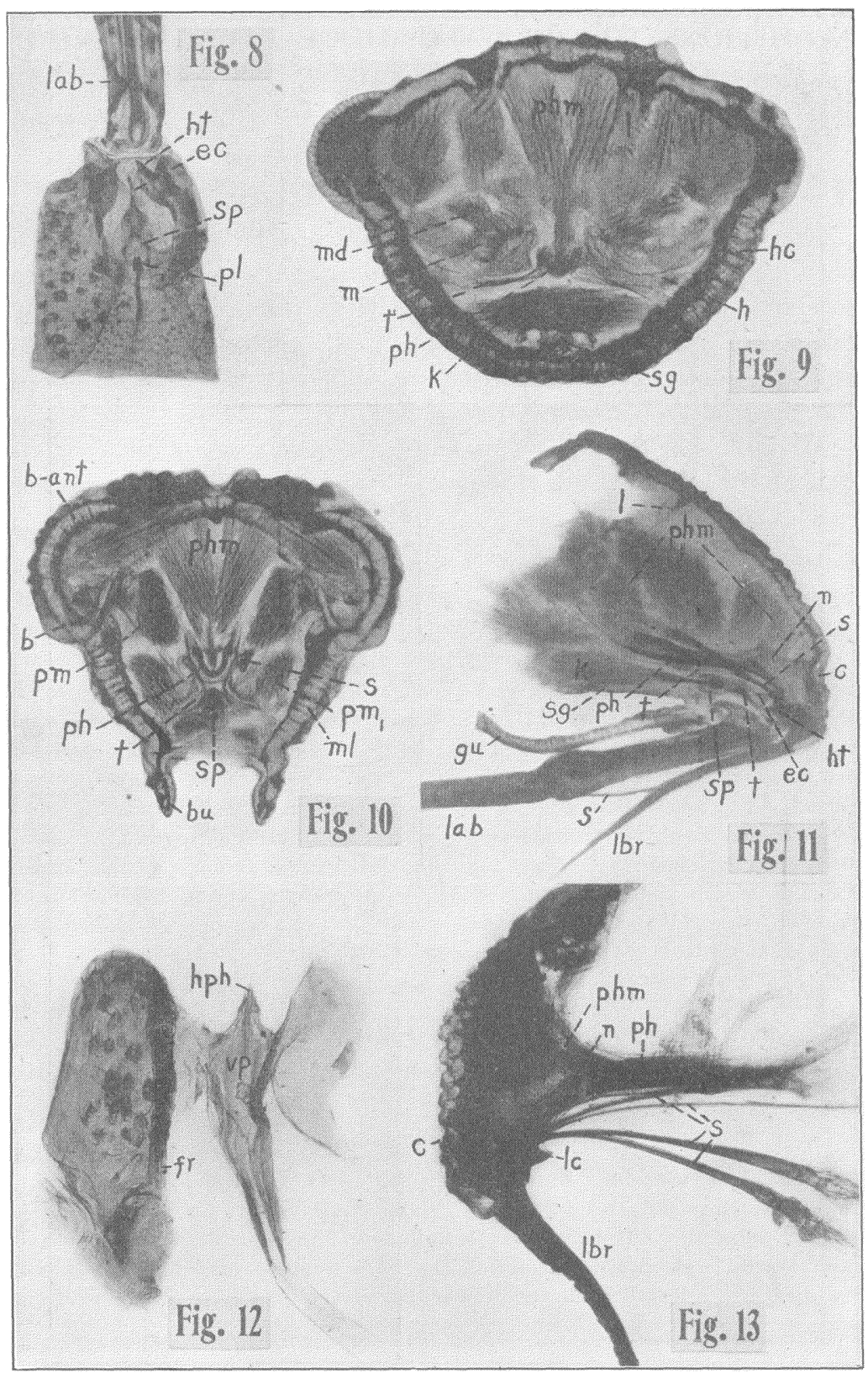

Tower-Mouth Parts of Squash Bug. 

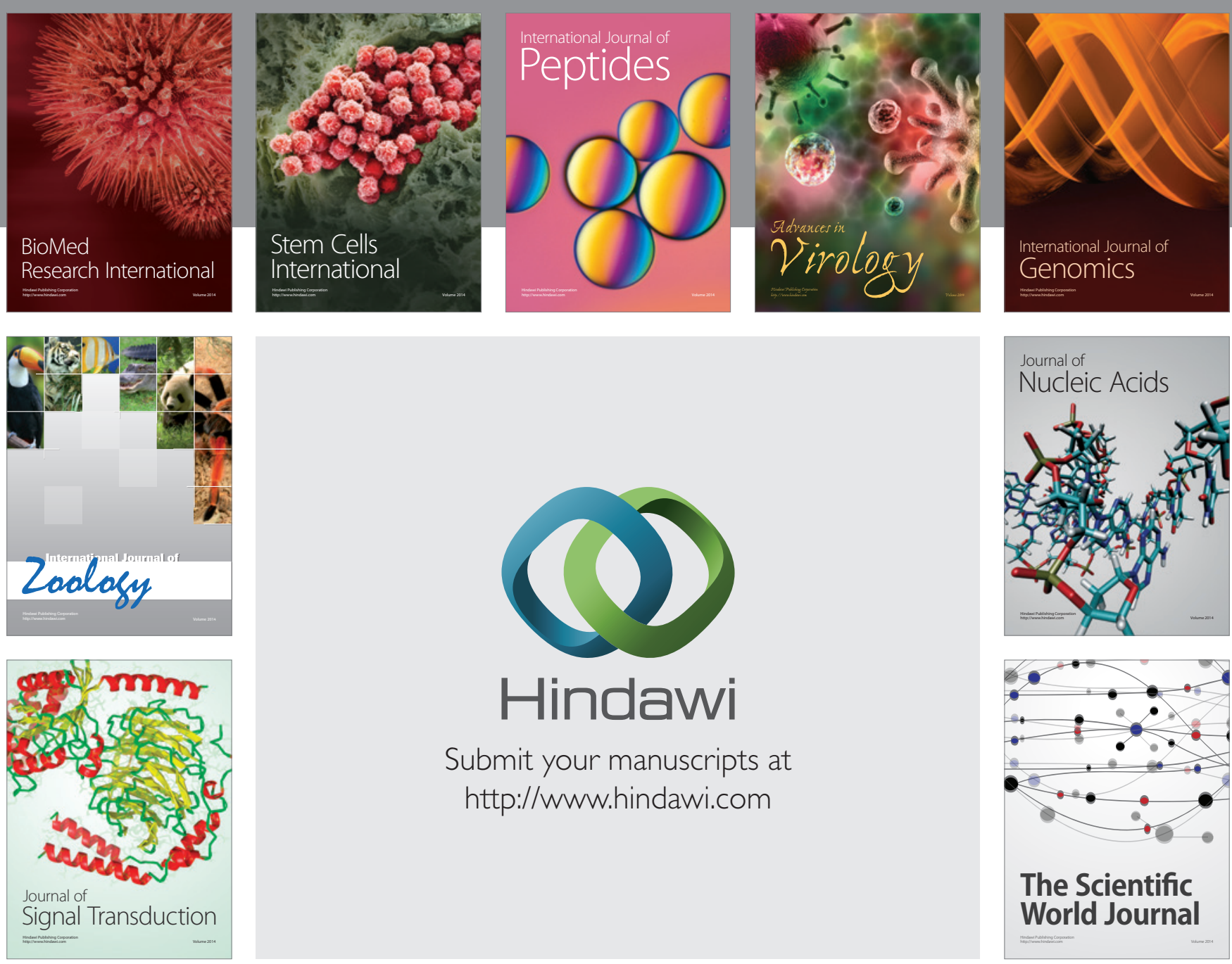

Submit your manuscripts at

http://www.hindawi.com
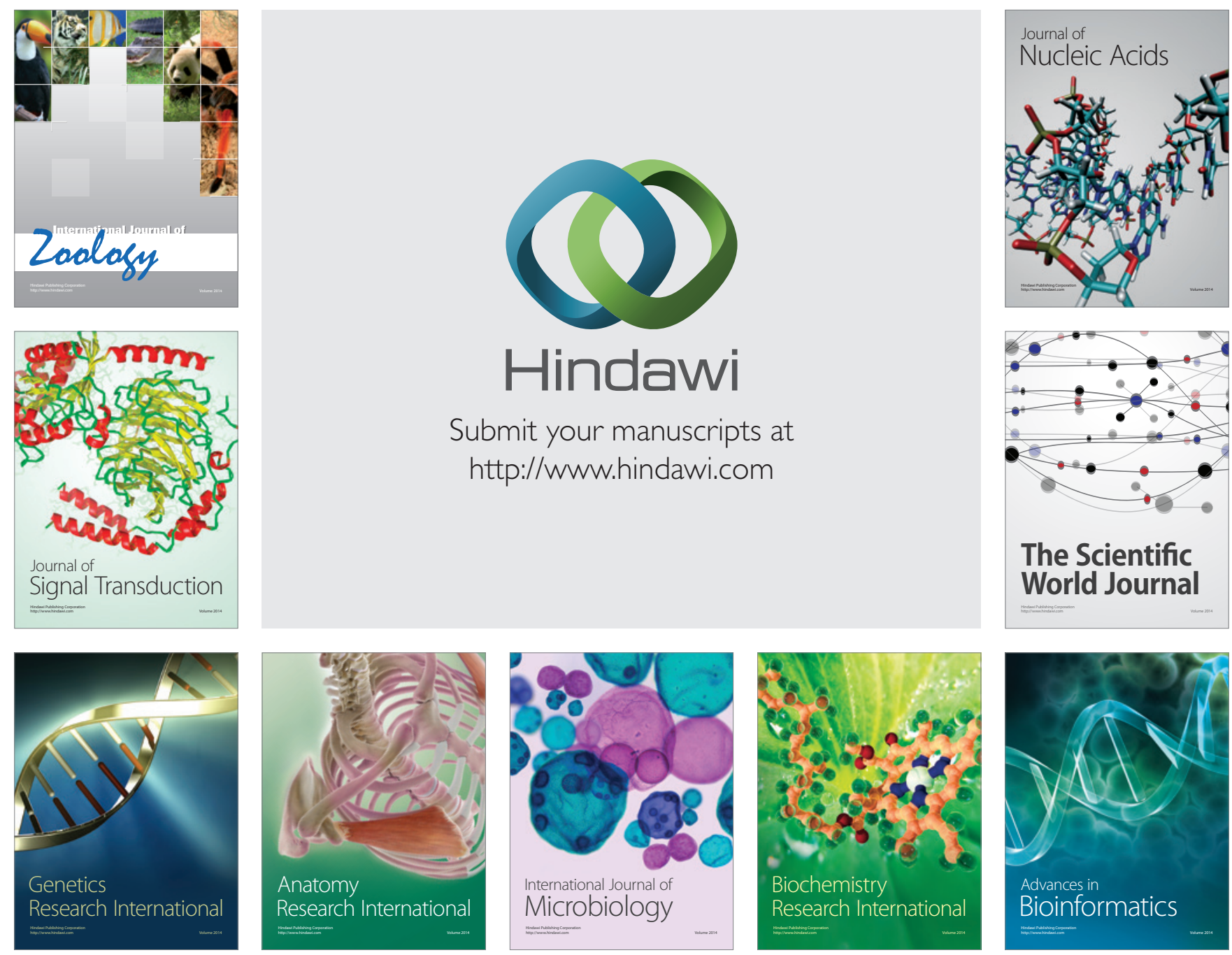

The Scientific World Journal
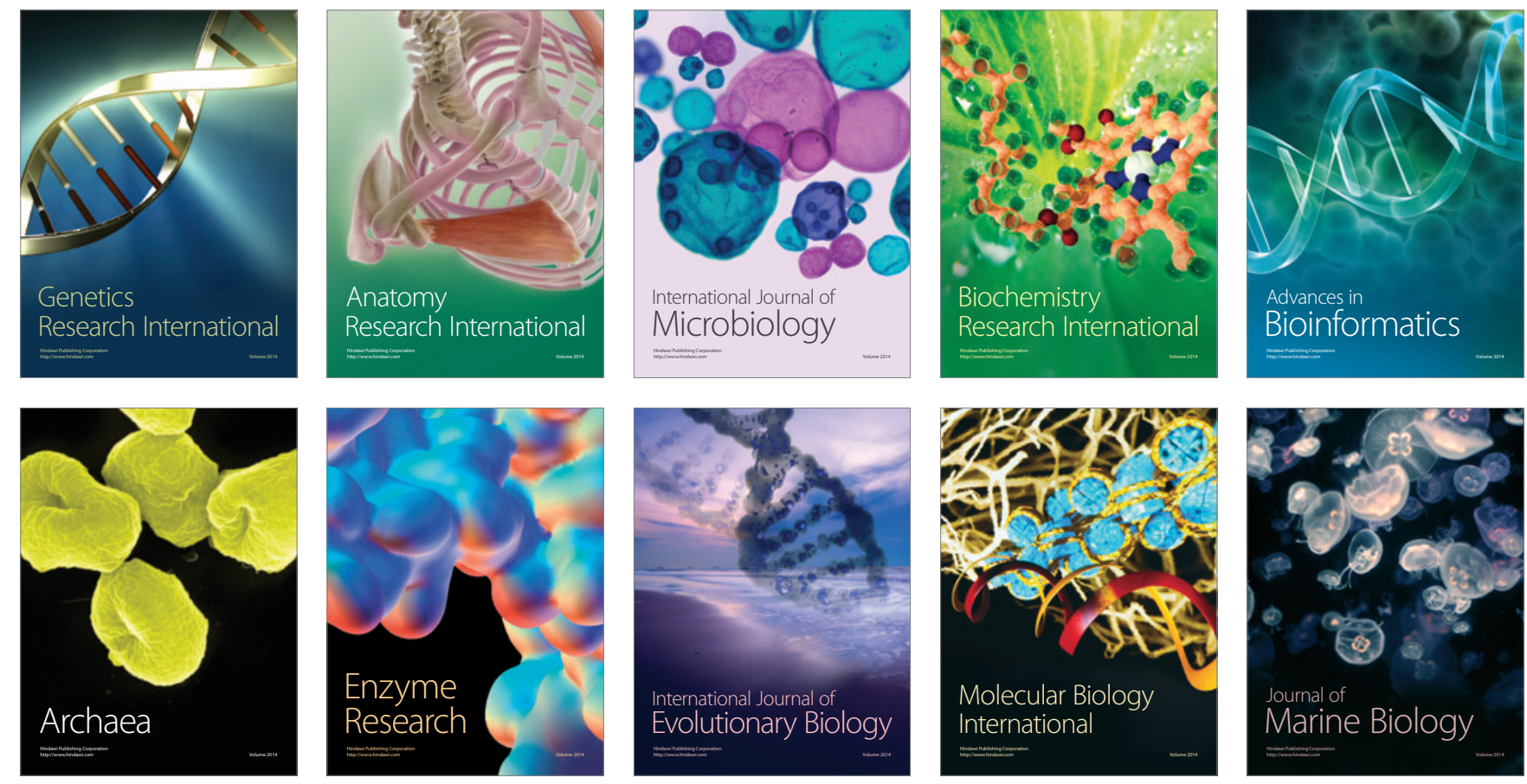